\title{
Use of Monensin Controlled-Release Capsules to Reduce Methane Emissions and Improve Milk Production of Dairy Cows Offered Pasture Supplemented with Grain
}

\author{
C. Grainger, ${ }^{\star 1}$ M. J. Auldist, ${ }^{\star 2}$ T. Clarke, ${ }^{\star}$ K. A. Beauchemin, † S. M. McGinn,† M. C. Hannah, ${ }^{\star}$ \\ R. J. Eckard, $\ddagger$ and L. B. Lowe§ \\ ${ }^{*}$ Department of Primary Industries, Ellinbank 3821, Victoria, Australia \\ †Agriculture and Agri-Food Canada Research Centre, Lethbridge, Alberta T1J 4B1, Canada \\ $\ddagger$ Faculty of Land and Food Resources, University of Melbourne, Victoria 3010, Australia \\ $\S$ Elanco Animal Health, Macquarie Park, New South Wales 2113, Australia
}

\begin{abstract}
We examined the effects of monensin, provided by controlled-release capsules, on the enteric methane emissions and milk production of dairy cows receiving ryegrass pasture and grain. In a grazing experiment, 60 Holstein-Friesian cows were assigned randomly to 1 of 2 groups (control or monensin). Cows in the monensin group received 2 controlled-release capsules, with the second capsule administered $130 \mathrm{~d}$ after the first. Milk production was measured for $100 \mathrm{~d}$ following insertion of each capsule. The sulfur hexafluoride tracer gas technique was used to measure enteric methane emissions for $4 \mathrm{~d}$ starting on $\mathrm{d} 25$ and 81 after insertion of the first capsule, and on d 83 after insertion of the second capsule. All cows grazed together as a single herd on a predominantly ryegrass sward and received $5 \mathrm{~kg} / \mathrm{d}$ of grain (as-fed basis). In a second experiment, 7 pairs of lactating dairy cows (control and monensin) were used to determine the effects of monensin controlled-release capsules on methane emissions and dry matter intake. Methane emissions were measured on d 75 after capsule insertion by placing cows in respiration chambers for $3 \mathrm{~d}$. Cows received fresh ryegrass pasture harvested daily and $5 \mathrm{~kg} / \mathrm{d}$ of grain. The release rate of monensin from the capsules used in both experiments was $240 \pm$ $0.072 \mathrm{mg} / \mathrm{d}$, determined over a $100-\mathrm{d}$ period in ruminally cannulated cows. The monensin dose was calculated to be 12 to $14.5 \mathrm{mg} / \mathrm{kg}$ of dry matter intake. There was no effect of monensin on methane production in either the grazing experiment ( $\mathrm{g} / \mathrm{d}, \mathrm{g} / \mathrm{kg}$ of milk solids) or the chamber experiment $(\mathrm{g} / \mathrm{d}, \mathrm{g} / \mathrm{kg}$ of dry matter intake). In the grazing study, there was no effect of
\end{abstract}

Received April 28, 2007.

Accepted December 2, 2007.

${ }^{1}$ Corresponding author: chris.grainger@dpi.vic.gov.au

${ }^{2}$ Current address: Fishing Monthly Group, PO Box 621, Queensland 4007, Australia. monensin on milk yield, but monensin increased milk fat yield by $51.5 \mathrm{~g} / \mathrm{d}$ and tended to increase milk protein yield by $18.5 \mathrm{~g} / \mathrm{d}$. Monensin controlled-release capsules improved the efficiency of milk production of grazing dairy cows by increasing the yield of milk solids. However, a higher dose rate of monensin may be needed to reduce methane emissions from cows grazing pasture. Key words: dairy cow, monensin, methane, pasture diet

\section{INTRODUCTION}

Methane is an important greenhouse gas, having many times the global warming potential of carbon dioxide (Intergovernmental Panel on Climate Change, 2001). Enteric methane emissions from cattle account for approximately $15 \%$ of global methane emissions (Lassey et al., 1997); consequently, considerable effort is being devoted to strategies that will lead to a reduction in enteric methane emissions. The most successful mitigation strategies will be those that lead to a profitable increase in milk or meat production, as well as those achieving a persistent reduction in enteric methane emissions.

Monensin is a polyether ionophore antibiotic and has been used for bloat relief in dairy cows grazing temperate legume-based pasture (Lowe et al., 1991). For grazing cattle, monensin is usually delivered via a controlled-release capsule to eliminate the need to incorporate monensin into supplementary feed. McGuffey et al. (2001) reviewed the effects of monensin controlledrelease capsules on milk production in studies conducted in Australia and New Zealand, with the diets offered varying from legume-based and ryegrass-based pastures to ryegrass-based pastures with grain supplements. Milk yield increased by an average of $1.1 \mathrm{~kg} / \mathrm{d}$ and milk protein yield increased by $30 \mathrm{~g} / \mathrm{d}$, but there was no effect on milk fat yield. 
For cows offered pasture-based diets, there is limited information on the effect of monensin on methanogenesis. Van Vugt et al. (2005) offered cows ryegrass-dominant pasture indoors and measured a $9 \%$ reduction in methane emissions ( $\mathrm{g} / \mathrm{kg}$ of DMI), which persisted for more than 2 mo after the monensin controlled-release capsules were given. The effect of monensin controlledrelease capsules on methanogenesis in dairy cattle offered pasture diets supplemented with grain has not been studied even though grain supplementation is common with pasture-based diets. With TMR, Odongo et al. (2007) reported a $3.6 \%$ reduction ( $\mathrm{g} / \mathrm{kg}$ of DMI) in methane for dairy cows fed a diet containing $24 \mathrm{mg}$ of monensin/kg of DM, which was sustained over a 6-mo period. However, others have shown that reductions in methane emissions caused by monensin may not persist beyond several weeks (Sauer et al., 1998; Guan et al., 2006).

The objective of our research was to establish whether monensin controlled-release capsules would reduce the enteric methane production of dairy cows offered pasture diets supplemented with grain. A further objective was to evaluate the effects on milk production, because a commensurate improvement in milk production could lead to adoption of monensin as a profitable strategy for methane abatement.

\section{MATERIALS AND METHODS}

Two experiments were conducted to measure the effects of monensin controlled-release capsules on milk production and methane emissions of dairy cows. The first experiment (grazing experiment) was conducted with cows grazing pasture, and a tracer gas technique was used to measure enteric methane emissions of the cows on pasture. The second experiment (chamber experiment) was conducted in respiratory chambers with a smaller number of cows to obtain precise estimates of methane production and DMI for cows consuming a diet similar to that consumed by the cows grazing pasture in the grazing experiment. All cows were from the experimental herd at the Department of Primary Industries-Victoria, Ellinbank Research Center (latitude $38^{\circ} 14^{\prime} \mathrm{S}$, longitude $145^{\circ} 56^{\prime} \mathrm{E}$ ), and both experiments were conducted in accordance with the Australian Code of Practice for the Care and Use of Animals for Scientific Purposes (www.nhmrc.gov.au).

\section{Grazing Experiment}

Sixty Holstein-Friesian cows, including 32 primiparous cows, were assigned randomly to 1 of 2 groups (control or monensin) balanced for means and variances of age, milk yield, and calving date as described by
Baird (1994). A monensin controlled-release capsule (Elanco Animal Health, Greenfield, IN) containing 32 $\mathrm{g}$ of monensin was placed into the rumen of half the cows in September 2005 (capsule 1), with a second capsule placed in the rumen of the same cows in January 2006, 130 d later (capsule 2). The monensin capsule was expected to release $320 \mathrm{mg} / \mathrm{d}$ of monensin over 100 d. The cows were $46 \pm 9$ DIM when the first monensin capsules were inserted. Milk production was recorded for $100 \mathrm{~d}$ following the insertion of each capsule. The 2 wk before starting the experiment were considered as a covariate period. During that time, the cows were producing, on average (mean $\pm \mathrm{SD}$ ), $25.5 \pm 6.0 \mathrm{~kg} / \mathrm{d}$ of milk, $1.029 \pm 0.270 \mathrm{~kg} / \mathrm{d}$ of milk fat, and $0.812 \pm 0.173$ $\mathrm{kg} / \mathrm{d}$ of milk protein, and their BW was $444 \pm 70 \mathrm{~kg}$.

Cows were weighed weekly during the experiment and milked twice daily through a common parlor at approximately 0700 and $1500 \mathrm{~h}$. Milk yield was measured daily for each cow by using a DeLaval ALPRO milk metering system (DeLaval International, Tumba, Sweden). One day per week, a separate a.m. and p.m. milk sample was taken from each cow by using inline milk meters. Samples were analyzed for concentrations of fat, protein, and lactose with a near-infrared milk analyzer (model 2000, Bentley Instruments, Chaska, $\mathrm{MN})$.

All cows grazed together as a single herd on a predominantly ryegrass sward. Cows also received $5 \mathrm{~kg} / \mathrm{d}$ of cracked barley grain (as-fed basis). Pasture availability was severely limited in February and March 2006; thus, the diet was supplemented with pasture silage that was allocated in accordance with pasture availability. Representative samples of feeds offered were collected each week and pooled over the two 100-d periods corresponding to the 2 capsules. The feed samples were ovendried and ground through a $0.5-\mathrm{mm}$ sieve, then analyzed by near-infrared spectroscopy by a commercial laboratory (FeedTest, Hamilton, Victoria, Australia). The analytical composition of feeds is shown in Table 1.

Methane Measurements. The sulfur hexafluoride $\left(\mathbf{S F}_{\mathbf{6}}\right)$ tracer technique involves placing a permeation tube containing ultrapure $\mathrm{SF}_{6}$ into the animal's rumen before starting an experiment. The permeation tubes used in the present experiment were manufactured in December 2004 by the National Institute of Water and Atmospheric Research, Wellington, New Zealand, and were filled with approximately $2.3 \mathrm{~g}$ of $\mathrm{SF}_{6}$. The release rate of $\mathrm{SF}_{6}$ was predetermined over a 10 -wk period by weighing each permeation tube weekly, and the average release of $\mathrm{SF}_{6}$ was $3.7 \pm 0.7 \mathrm{mg} / \mathrm{d}$.

The permeation tubes containing $\mathrm{SF}_{6}$ were placed in the rumen of 30 of the 60 cows ( 15 control cows and 15 monensin cows) 1 wk before the first measurements of methane were performed. Methane emissions were 
Table 1. Analytical composition of grains and pastures offered in the grazing and chamber experiments ${ }^{1}$

\begin{tabular}{lccc}
\hline & \multicolumn{2}{c}{ Grazing experiment } & \\
\cline { 2 - 3 } & $\begin{array}{c}\text { First } \\
100 \mathrm{~d} \\
\text { (capsule 1) }\end{array}$ & $\begin{array}{c}\text { Second } \\
100 \mathrm{~d} \\
\text { (capsule 2) }\end{array}$ & $\begin{array}{c}\text { Chamber } \\
\text { experiment }\end{array}$ \\
\hline Item & & & \\
Pasture & 75.8 & 77.4 & 71.1 \\
Apparent digestible DM, \% & 21.2 & 19.3 & 16.4 \\
CP, \% of DM & 49.4 & 47.5 & 54.4 \\
NDF, \% of DM & & & \\
Grain & 83.3 & 86.7 & 85.8 \\
Apparent digestible DM, \% & 12.9 & 11.8 & 10.7 \\
CP, \% of DM & 8.2 & 5.8 & 6.6 \\
ADF, \% of DM & & & \\
Pasture silage & & 71.6 & \\
Apparent digestible DM, \% & & 16.0 & \\
CP, \% of DM & & 50.2 & \\
NDF, \% of DM & &
\end{tabular}

${ }^{1}$ Cows received $5 \mathrm{~kg} / \mathrm{d}$ of barley grain and a predominantly ryegrass pasture, except during February and March in the second 100-d period, when cows were offered $5 \mathrm{~kg} / \mathrm{d}$ of cracked triticale grain and pasture silage in addition to pasture.

measured for 4 consecutive days twice during the first 100-d period corresponding to capsule 1 (starting on d 25 and 81 after insertion) and once corresponding to capsule 2 (starting on d 83 after insertion). During each day of measurement, a yoke-shaped evacuated canister was placed around the neck of each cow. The canisters were used to draw a sample of air from around the nasal cavity, consisting of respired and eructated gases. The canisters were evacuated daily and $\mathrm{SF}_{6}$ and methane concentrations were analyzed by gas chromatography. Air samples were collected in canisters located upwind from the grazing cows to estimate background $\mathrm{SF}_{6}$ and methane concentrations.

Methane emission $\left(\mathrm{Q}_{\mathrm{CH} 4} ; \mathrm{g} / \mathrm{d}\right)$ was calculated by using the $\mathrm{SF}_{6}$ and methane mixing ratio $(\mu \mathrm{mol} / \mathrm{mol})$ sampled by the canisters on the cows $\left(\mathrm{C}_{\mathrm{SF} 6}\right.$ and $\mathrm{C}_{\mathrm{CH} 4}$, respectively) and those used for background $\left(\mathrm{C}_{\mathrm{SF} 6}^{\mathrm{b}}\right.$ and $\mathrm{C}_{\mathrm{CH} 4}^{\mathrm{b}}$, respectively), and by the predetermined $\mathrm{SF}_{6}$ release rate $\left(\mathrm{Q}_{\mathrm{SF} 6} ; \mathrm{g} / \mathrm{d}\right)$ from the permeation tubes (equation [1]), where MW is the molecular weights of the gases.

$$
Q_{\mathrm{CH} 4}=\frac{C_{\mathrm{CH} 4}-C_{\mathrm{CH} 4}^{\mathrm{b}}}{C_{\mathrm{SF} 6}-C_{\mathrm{SF} 6}} Q_{\mathrm{SF} 6} \frac{M W_{\mathrm{CH} 4}}{M W_{\mathrm{SF} 6}} .
$$

The $\mathrm{SF}_{6}$ tracer technique as used in the grazing experiment could detect differences in methane emissions of $8.6 \%$ or greater. Further details of the $\mathrm{SF}_{6}$ tracer technique and analysis of the concentration of methane and $\mathrm{SF}_{6}$ in the canisters as used in this study were reported previously (Grainger et al., 2007).

\section{Chamber Experiment}

The experiment was conducted with 8 pairs of lactating dairy cows (one cow with and one without a monensin controlled-release device), including 3 primiparous cow pairs, over a $36-\mathrm{d}$ period. The cows had previously been trained to accept halters and headstall restraints. The experiment was conducted during November and December (late spring to early summer) 2005, and monensin controlled-release capsules were administered to the cows $75 \mathrm{~d}$ before measurements began. Cows were moved in pairs from the main herd to a metabolism facility and then placed in individual respiration chambers. The cows were initially held in metabolism stalls for $4 \mathrm{~d}$, and each cow was fitted with a body harness and collection apparatus to enable separate collection of urine and feces. This adaptation period facilitated a smooth transition into the 2 chambers, where methane and intake were measured over $3 \mathrm{~d}$.

Details of the operation of the chambers have been reported previously (Grainger et al., 2007) and are only briefly presented here. Within the chambers, the volume of air $\left(41.5 \mathrm{~m}^{3}\right)$ was independently recycled back into each chamber after passing through filters, under conditions that maintained the air at a $55 \%$ relative humidity and $20^{\circ} \mathrm{C}$. A small portion of this recycled air was continuously removed and replaced with fresh air drawn in through an inlet remote from the chambers. A sample of the fresh and exhausted air was pumped through a gas analyzer (Xentra 4100C1, Servomex, East Sussex, UK), and the methane mixing ratio ( $\mu \mathrm{mol} /$ mol), exhaust airflow rate, and relative humidity and temperature of the exhaust air were recorded every 10 s. In each 12-min period, the airstream at the common inlet and 2 exhaust ducts (chambers 1 and 2) was sampled for 4 min each. A check on the gas analyzer was conducted every $4 \mathrm{~h}$ and any drift in the measurement was corrected. Before and after the experiment, the accuracy of the entire system was checked by releasing a known quantity of methane into each chamber and then comparing against the chamber emission, where the latter was simply a mass balance of exhaust minus intake amounts.

Cows were weighed before they entered the metabolism stalls and after they exited the chambers. They were milked twice daily with a portable milking apparatus. Fresh ryegrass pasture that was harvested daily was provided twice daily to ensure ad libitum intake. Cows also received $5 \mathrm{~kg} / \mathrm{d}$ of cracked barley (as-fed basis) in 2 daily feedings. All feed offered and refused was weighed daily. Samples of feed and refusals were dried to determine DM content, and total daily DMI was calculated per cow. Representative samples of the pasture and grain were collected daily and pooled to form 4 
samples of each feed for the experiment. The samples were oven-dried and ground through a $0.5-\mathrm{mm}$ sieve, then analyzed by near-infrared spectroscopy by a commercial laboratory (FeedTest). Analytical composition of the feeds is reported in Table 1.

\section{Release Rate of Monensin Controlled- Release Capsules}

The release rate of monensin from the capsules was determined by placing 2 capsules in the rumen of each of 5 ruminally cannulated lactating dairy cows. The capsules were removed approximately $100 \mathrm{~d}$ after insertion, and the distance from the orifice to the back of the piston was measured for each capsule. The capsule was then turned over and the measurement was repeated. The release rate for each capsule was calculated by using the average of the 2 measurements. Because the capsules used in the first and second $100 \mathrm{~d}$ of the grazing experiment were from 2 different lots, the entire procedure was repeated for the second batch of capsules.

\section{Statistical Analyses}

Data (milk yield and composition, BW change) for the grazing experiment were averaged for each cow for the two 100-d periods corresponding to capsules 1 and 2 . These means were analyzed by analysis of covariance in GenStat (VSN International Ltd., 2007) by using a full factorial treatment structure specified as treatment $\times$ age $\times$ capsule period, where age was a 2-level factor distinguishing between multiparous and primiparous cows. The blocking structure was that of a split-plot design, with cow split for capsule period. The covariate for each variable was the pretreatment measurement averaged over the 2 -wk covariate period.

The methane data obtained by using the $\mathrm{SF}_{6}$ tracer technique were analyzed differently because of substantial quantities of missing data, as well as having 3 methane measurement periods ( 2 for capsule 1,1 for capsule 2) and fewer cows (15/group). This analysis used a general linear mixed model with fixed factorial effects for treatment $\times$ measurement period $\times$ age. A linear covariate for permeation tube release rate and covariates for calving date and milk yield, which were used initially to allocate cows to treatment, were also included in the model. Factorial random effects were included in the model for cow $\times$ day of measurement (12 d corresponding to the $4 \mathrm{~d}$ in each of the 3 methane measurements periods), and an autoregressive order one process was defined for repeated measurements over the $4 \mathrm{~d}$ within measurement periods and cows. After testing for significance, the model was simplified by removing nonsignificant terms. Analysis was performed by using REML in GenStat (VSN International Ltd., 2007). Eight data points for methane were identified as outliers in graphs of residuals. These included 1 very low estimate for 1 cow on $1 \mathrm{~d}$ during the first measurement period for capsule 1, all $4 \mathrm{~d}$ for $1 \mathrm{cow}$, and 3 other outliers for capsule 2 . In addition, there were 55 points with missing values. Analysis was performed on the remaining 297 methane data points.

Methane emissions per kilogram of milk solids were calculated for each capsule as follows. First, methane data were averaged across days for each cow in the 100d period corresponding to the insertion of each capsule. For the first capsule, this meant that methane data for each cow were an average of 8 measurements (2 measurement periods $\times 4 \mathrm{~d}$ ). For the second capsule, the methane data for each cow were an average of 4 measurements ( 1 measurement period $\times 4 \mathrm{~d}$ ). Second, milk solids data were averaged for each cow over each 100-d period corresponding to the insertion of each capsule. These data were then expressed as a ratio of methane to milk solids. Analysis was performed by using ANOVA in GenStat (VSN International Ltd., 2007) with a treatment structure of treatment $\times$ age $\times$ period, and a split-plot blocking structure of cow split for period. Residuals were examined for evidence of nonconstant variance.

For the chamber experiment, DMI was averaged over the $3 \mathrm{~d}$ that each cow was in a chamber. The averaged data were analyzed by analysis of covariance with a single-factor treatment structure (control vs. monensin) and a blocking structure of cow within pair. One pair of cows was excluded because of the failure of 1 of the cows to adapt to the metabolism stalls, reducing the data to 7 pairs. Because the possibility of any chamber effect on intake variables seemed implausible, a factor for chamber was not included in the model, permitting analysis by balanced ANOVA or analysis of covariance. The methane and methane-to-DMI data were obtained by averaging data over the $3 \mathrm{~d}$ each cow was in the chamber before taking any ratios. These were analyzed by ANOVA with a single-factor treatment structure (control vs. monensin), and a blocking structure of cow within pair by chamber. All analyses were followed by graphs of residuals vs. fitted values, histograms, and normal probability plots to check the usual constant variance and normal distribution assumptions.

\section{RESULTS AND DISCUSSION}

\section{Release Rate of Monensin from Controlled- Release Capsules}

The piston in the monensin capsules moved, on average, $0.75 \mathrm{~mm} / \mathrm{d}$ over $100 \mathrm{~d}$ and was not different for the 2 
Table 2. Effects of monensin controlled-release capsules on methane emissions from lactating dairy cows grazing pasture supplemented with grain (grazing experiment, $\mathrm{n}=15$ per treatment)

\begin{tabular}{|c|c|c|c|c|c|}
\hline Capsule & $\begin{array}{l}\text { Days after } \\
\text { insertion } \\
\text { of capsule }\end{array}$ & Control & Monensin & LSD & $P$-value ${ }^{1}$ \\
\hline & & & $-g / d$ & - & \\
\hline 1 & 25 & 273 & 304 & 41.9 & 0.93 \\
\hline 1 & 81 & 373 & 404 & 41.9 & 0.93 \\
\hline 2 & 83 & 376 & 386 & 41.9 & 0.67 \\
\hline \multirow[t]{2}{*}{ Average } & & 341 & 365 & 30.2 & 0.94 \\
\hline & & \multicolumn{3}{|c|}{ — $\mathrm{g} / \mathrm{kg}$ of milk solids ${ }^{2}-$} & \\
\hline $1^{3}$ & 25 and 81 & 206 & 203 & 37.7 & 0.45 \\
\hline 2 & 83 & 295 & 276 & 37.7 & 0.16 \\
\hline Average & & 250 & 240 & 30.3 & 0.47 \\
\hline
\end{tabular}

${ }^{1}$ Determined by using a one-tailed test.

${ }^{2}$ Milk solids data were the average for each cow over the $100 \mathrm{~d}$ after insertion of each monensin controlled-release capsule.

${ }^{3}$ Methane data for each cow was an average of 2 measurement periods for capsule 1 .

lots used in the 2 dosing periods ( $P=0.98)$. The expected movement was $1 \mathrm{~mm} / \mathrm{d}$, which would have released 320 $\mathrm{mg} / \mathrm{d}$ of monensin. Based on the measured rate of piston movement, the average monensin dose for capsules used in this research was $240 \pm 23 \mathrm{mg} / \mathrm{d}$, or $75 \%$ of the expected release rate. Because the release rate was slower than expected, during the grazing experiment the second capsules were administered $130 \mathrm{~d}$ after the first capsules to ensure they were fully depleted.

\section{Methane Emissions and DMI}

There was no effect of monensin on methane production in either the grazing experiment $(\mathrm{g} / \mathrm{d}, \mathrm{g} / \mathrm{kg}$ of milk solids; Table 2) or the chamber experiment $(\mathrm{g} / \mathrm{d}, \mathrm{g} / \mathrm{kg}$ of DMI; Table 3). However, significant $(P<0.001)$ differences were detected in methane emissions (LSD $=38.1$ $\mathrm{g} / \mathrm{d}$ ) between multiparous (382 $\mathrm{g} / \mathrm{d}$ ) and primiparous cows $(324 \mathrm{~g} / \mathrm{d})$. The difference attributable to age group

Table 3. Effects of monensin controlled-release capsules on methane emissions and DMI of lactating dairy cows measured over $3 \mathrm{~d}$ in chambers for cows offered a diet of cut pasture supplemented with grain (chamber experiment; $\mathrm{n}=7$ per treatment) ${ }^{1}$

\begin{tabular}{|c|c|c|c|c|}
\hline Item & Control & Monensin & LSD & $P$-value ${ }^{2}$ \\
\hline $\begin{array}{l}\text { Methane } \\
\mathrm{g} / \mathrm{d} \\
\mathrm{g} / \mathrm{kg} \text { of DMI }\end{array}$ & $\begin{array}{l}309 \\
16.7\end{array}$ & $\begin{array}{r}306 \\
17.0\end{array}$ & $\begin{array}{c}58.5 \\
3.21\end{array}$ & $\begin{array}{l}0.45 \\
0.95\end{array}$ \\
\hline $\begin{array}{l}\mathrm{DMI} \\
\mathrm{kg} / \mathrm{d} \\
\mathrm{kg} / \mathrm{BW}^{0.75}\end{array}$ & $\begin{array}{c}18.38 \\
0.179\end{array}$ & $\begin{array}{c}18.02 \\
0.172\end{array}$ & $\begin{array}{l}2.488 \\
0.0232\end{array}$ & $\begin{array}{l}0.76 \\
0.76\end{array}$ \\
\hline
\end{tabular}

\footnotetext{
${ }^{1}$ Measurements were performed $75 \mathrm{~d}$ after insertion of the monensin controlled-release capsules.

${ }^{2}$ Determined by using a one-tailed test.
}

probably reflected differences in intake of these cows, because methane emissions are proportional to DMI (Grainger et al., 2007).

The lack of effect of monensin on methane emissions disagrees with the only other published study with cows consuming pasture (Van Vugt et al., 2005), in which methane emissions ( $\mathrm{g} / \mathrm{kg}$ of DMI) decreased by 9 to $10 \%$ for at least 2 mo after insertion of a controlled-release capsule. The discrepancy between studies is probably explained by the different dose of monensin per kilogram of DMI used. The release rate of the controlledrelease capsule in the study of Van Vugt et al. (2005) was not measured but was assumed to be $320 \mathrm{mg} / \mathrm{d}$. With a measured DMI of $10.8 \mathrm{~kg} / \mathrm{d}$, the monensin addition to the diet would have been $30 \mathrm{mg} / \mathrm{kg}$ of DMI in that study. In our study, only $240 \mathrm{mg} / \mathrm{d}$ of monensin was released from the controlled-release capsules. In the chamber experiment, measured DMI averaged 18 $\mathrm{kg} / \mathrm{d}$; thus, the monensin addition to the diet was only $13 \mathrm{mg} / \mathrm{kg}$ of DMI. Dry matter intake was not measured in the grazing experiment but was estimated by using feeding standards (Standing Committee on Agriculture, 1990) and data for milk production, BW, and BW change. Calculated DMI was $20 \mathrm{~kg} / \mathrm{d}$ during the first $100 \mathrm{~d}$ corresponding to the first capsule and $16.5 \mathrm{~kg} / \mathrm{d}$ during the next $100 \mathrm{~d}$ corresponding to the second capsule. Thus, monensin addition to the diet would have been approximately 12 and $14.5 \mathrm{mg} / \mathrm{kg}$ of DMI for the first and second capsules, respectively. Our inclusion rates of monensin per kilogram of DMI were only approximately $44 \%$ of the rate used by Van Vugt et al. (2005), which likely accounts for the lack of effects of monensin on methane emissions in the short and long term during our study.

Other studies that used rations containing preserved forages and concentrates with monensin added in the form of a premix at rates of $24 \mathrm{mg} / \mathrm{kg}$ of DMI with dairy cattle (Sauer et al., 1998; Odongo et al., 2007) and 33 $\mathrm{mg} / \mathrm{kg}$ of DMI for beef cattle (McGinn et al., 2004; Guan et al., 2006) measured reductions in methane emissions (g/kg of DMI) ranging from 3.6\% (Odongo et al., 2007) to 27 to $30 \%$ (Guan et al., 2006). From the results of our study, it can be surmised that the rate of monensin released from controlled-release capsules used for bloat control in dairy cows grazing pasture may be below the level needed to reduce methane emissions.

\section{DMI, Milk Production, and BW Change}

In agreement with Van Vugt et al. (2005) and McGinn et al. (2004), there was no effect of monensin on DMI (Table 3). Effects of monensin on DMI are generally small, 10\% (Sauer et al., 1998) or less, and are consequently difficult to detect. 
Table 4. Effects of monensin controlled-release capsules on milk production, milk composition, and BW change of dairy cows grazing pasture supplemented with grain (grazing experiment; $n=30$ per treatment) ${ }^{1}$

\begin{tabular}{|c|c|c|c|c|c|c|c|c|}
\hline \multirow[b]{2}{*}{ Item } & \multicolumn{2}{|c|}{ Capsule 1} & \multicolumn{2}{|c|}{ Capsule 2} & \multicolumn{2}{|c|}{ Main effect ${ }^{2}$} & \multirow[b]{2}{*}{$\mathrm{LSD}^{3}$} & \multirow[b]{2}{*}{$P$-value ${ }^{4}$} \\
\hline & Control & Monensin & Control & Monensin & Control & Monensin & & \\
\hline Milk yield, kg/d & 22.55 & 22.83 & 15.58 & 16.18 & 19.06 & 19.51 & 0.668 & 0.17 \\
\hline Fat, $\%$ & 3.94 & 4.15 & 4.77 & 4.86 & 4.35 & 4.51 & 0.188 & 0.11 \\
\hline Fat yield, kg/d & 0.882 & 0.946 & 0.741 & 0.780 & 0.812 & 0.863 & 0.0369 & 0.005 \\
\hline Protein, $\%$ & 3.23 & 3.25 & 3.61 & 3.62 & 3.42 & 3.44 & 0.061 & 0.63 \\
\hline Protein yield, kg/d & 0.724 & 0.740 & 0.561 & 0.582 & 0.643 & 0.661 & 0.0189 & 0.06 \\
\hline Lactose, \% & 5.10 & 5.11 & 5.07 & 5.08 & 5.09 & 5.09 & 0.052 & 0.80 \\
\hline Lactose yield, $\mathrm{kg} / \mathrm{d}$ & 1.149 & 1.163 & 0.791 & 0.820 & 0.970 & 0.992 & 0.0352 & 0.21 \\
\hline Fat + protein, kg/d & 1.606 & 1.687 & 1.302 & 1.362 & 1.454 & 1.524 & 0.0498 & 0.005 \\
\hline BW change, $\mathrm{kg} / \mathrm{d}$ & 0.75 & 0.75 & 0.07 & 0.13 & 0.41 & 0.44 & 0.109 & 0.57 \\
\hline
\end{tabular}

\footnotetext{
${ }^{1}$ Means for each capsule are averaged over the 100-d period following insertion of each capsule.

${ }^{2}$ Main effect of monensin averaged over capsules 1 and 2 .

${ }^{3}$ LSD for the main effect of monensin.

${ }^{4}$ One-sided $P$-value for the main effect of monensin. The capsule number $\times$ treatment interaction was always nonsignificant $(P>0.05)$; hence, $P$-values for the interaction are not presented in the table.
}

There was no treatment $\times$ age interaction for milk production and BW change variables, so the data were averaged across age groups. Monensin increases the availability of glucose precursors by increasing the ratio of propionate to acetate in the rumen (Schelling, 1984), which should favor increased milk yield and decreased milk fat percentage. We measured a $0.45 \mathrm{~L} /$ d increase in milk yield (averaged over both capsules in the grazing experiment) with the addition of monensin, but this increase was not significant $(P=0.167$; Table 4$)$. Other studies with pasture-based diets have measured increases in milk yield ranging from 0.75 to $1.4 \mathrm{~kg} / \mathrm{d}$ (Lowe et al., 1991; Hayes et al., 1996; Beckett et al., 1998). There were no significant effects of monensin on BW change over the duration of the experiment.

Cows administered monensin produced $51.5 \mathrm{~g} / \mathrm{d}$ more milk fat and $70.5 \mathrm{~g} / \mathrm{d}$ more milk solids than control cows. This finding agrees with Beckett et al. (1998), who conducted a large field study evaluating monensin controlled-release capsules by using 12 Australian herds that were grazing pasture supplemented with concentrates. It also agrees with Hayes et al. (1996), who measured a significant increase in milk fat yield for cows from 3 herds in New Zealand during the second month after monensin controlled-release capsules were administered. The cows grazed ryegrass-dominant pastures in the New Zealand study. However, other studies that have evaluated monensin controlled-release capsules reported no increase in milk fat yield when cows were offered legume-based pastures without grain supplementation in Australia and New Zealand (Lowe et al., 1991). Inconsistent effects of monensin on milk fat yield among studies might be due to the range in diets offered. It is also possible that the controlled-release capsules used in those pasture-based studies provided different dose rates of monensin, although release rates were not determined in the studies of Lowe et al. (1991) and Hayes et al. (1996).

We also measured an increase in milk protein yield $(18.2 \mathrm{~g} / \mathrm{d})$ with the addition of monensin (Table 4$)$, which approached significance $(P=0.063)$. A trend for increased milk protein yield is in agreement with Beckett et al. (1998), who used a diet similar to that used in our study, and Hayes et al. (1996), who used a pastureonly diet. Lowe et al. (1991) measured an increase of $30 \mathrm{~g} / \mathrm{d}$ in milk protein yield with the addition of monensin to cows offered legume-based pastures.

Milk protein percentage was not affected by monensin, in agreement with previous studies (Lowe et al., 1991; Beckett et al., 1998). Monensin often causes a reduction in milk fat percentage (Lowe et al., 1991; Phipps et al., 2000). However, in our study there was no effect of monensin on milk fat percentage, in agreement with Beckett et al. (1998), who fed a diet similar to that in our study.

When examined over a range of studies, monensin controlled-release boluses have typically improved the production efficiency of dairy cows grazing pasture, but whether the response has occurred as increased yield of milk or milk components has been inconsistent. It is unclear whether the variability in response is due to the genetic potential of the cows, diet composition, dose rate of monensin, or other factors. The diets offered in the few studies reviewed above varied from legumebased and ryegrass-based pastures to ryegrass-based pastures with grain supplementation; however, the dose rate of monensin delivered by the controlled-release capsule used in many of the studies was not measured. Yet it is well established that production responses to monensin supplementation are dose dependent (Phipps et al., 2000). Our study indicates that the release rate of monensin from controlled-release 
capsules can deviate from the stated release rate; thus, it is important to measure the release rate of monensin from capsules in future studies to better understand the effects of the monensin dose rate on milk production.

\section{CONCLUSIONS}

Monensin controlled-release capsules providing 240 $\mathrm{mg} / \mathrm{d}$ (12 to $14.5 \mathrm{mg} / \mathrm{kg}$ of DMI) improved the efficiency of milk production of grazing dairy cows by increasing the output of milk solids, particularly milk fat. However, there were no short- or long-term reductions in enteric methane emissions at these release rates. It is possible that a higher dose rate of monensin is needed to reduce methane production in the rumen. A dose rate study needs to be conducted to properly ascertain the value of monensin as a profitable methane mitigation strategy for cows offered pasture-based diets. This type of research is important because few opportunities exist in grazing systems to mitigate methane emission by diet manipulation, unlike the situation for dairy farms feeding TMR.

\section{ACKNOWLEDGMENTS}

We thank D. Mapleson, R. Case, and A. Hookey (Department of Primary Industries, Victoria, Australia) for caring for the animals and A. Cavanagh (AgResearch, Palmerston North, New Zealand) for performing the gas analysis. The Department of Primary IndustriesVictoria, the Victorian Greenhouse Strategy (Melbourne, Australia), Elanco Animal Health Australia, and AgResearch, New Zealand, funded this study.

\section{REFERENCES}

Baird, D. B. 1994. The design of experiments with covariates. PhD Thesis. University of Otago, Dunedin, New Zealand.

Beckett, S., I. Lean, R. Dyson, W. Tranter, and L. Wade. 1998. Effect of monensin on the reproduction, health and milk production of dairy cows. J. Dairy Sci. 81:1563-1573.
Grainger, C., T. Clarke, S. M. McGinn, M. J. Auldist, K. A. Beauchemin, M. C. Hannah, G. C. Waghorn, H. Clark, and R. J. Eckard. 2007. Methane emissions from dairy cows measured using the sulfur hexafluoride $\left(\mathrm{SF}_{6}\right)$ tracer and chamber techniques. J. Dairy Sci. 90:2755-2766.

Guan, H., K. M. Wittenberg, K. H. Ominski, and D. O. Krause. 2006. Efficacy of ionophores in cattle diets for mitigation of enteric methane. J. Anim. Sci. 84:1896-1906

Hayes, D. P., D. U. Pfeiffer, and N. B. Williamson. 1996. Effect of intraruminal monensin capsules on reproductive performance and milk production of dairy cows fed pasture. J. Dairy Sci. 79:1000-1008.

Intergovernmental Panel on Climate Change. 2001. Climate Change 2001: The Scientific Basis. Cambridge University Press, Cambridge, UK

Lassey, K. R., M. J. Ulyatt, R. J. Martin, C. F. Walker, and I. D. Shelton. 1997. Methane emissions measured directly from grazing livestock in New Zealand. Atmos. Environ. 31:2905-2914.

Lowe, L. B., G. J. Ball, V. R. Carruthers, R. C. Dobos, G. A. Lynch, P. J. Moate, P. R. Poole, and S. C. Valentine. 1991. Monensin controlled-release capsule for control of bloat in pastured dairy cows. Aust. Vet. J. 68:17-28.

McGinn, S. M., K. A. Beauchemin, T. Coates, and D. Colombatto. 2004. Methane emissions from beef cattle: Effect of monensin, sunflower oil, enzymes, yeast and fumaric acid. J. Anim. Sci. 82:3346-3356.

McGuffey, R. K., L. F. Richardson, and J. I. D. Wilkinson. 2001 Ionophores for dairy cattle: Current status and future outlook. J. Dairy Sci. 84 (E Suppl.):E194-E203.

Odongo, N. E., R. Bagg, G. Vessie, P. Dick, M. M. Or-Rashid, S. E. Hook, J. T. Gray, E. Kebreab, J. France, and B. W. McBride. 2007. Long-term effects of feeding monensin on methane production in lactating dairy cows J. Dairy Sci. 90:1781-1788.

Phipps, R. H., J. I. D. Wilkinson, L. J. Jonker, M. Tarrant, A. K. Jones, and A. Hodge. 2000. Effect of monensin on milk production of Holstein-Friesian dairy cows. J. Dairy Sci. 83:2789-2794.

Sauer, F. D., V. Fellner, R. Kinsman, J. K. G. Kramer, H. A. Jackson, A. J. Lee, and S. Chen. 1998. Methane output and lactation response in Holstein cattle with monensin or unsaturated fat added to the diet. J. Anim. Sci. 76:906-914.

Schelling, G. T. 1984. Monensin mode of action in the rumen. J. Anim. Sci. 58:1518-1527.

Standing Committee on Agriculture. 1990. Feeding Standards for Australian Livestock: Ruminants. Commonwealth Scientific and Industrial Research Organisation, Collingwood, Victoria, Australia.

Van Vugt, S. J., G. C. Waghorn, D. A. Clark, and S. L. Woodward. 2005. Impact of monensin on methane production and performance of cows fed forage diets. Proc. N. Z. Soc. Anim. Prod. 65:362-366.

VSN International Ltd. 2007. GenStat. 9th ed. VSN International Ltd., Hemel Hempstead, UK. 